\title{
One-Click Russian Populism in Putinesque The Knight of the Burning Pestle
}

\author{
by Kevin A. Quarmby. Published in 2019 Issue 1.
}

For the production: The Knight of the Burning Pestle (2019, Barbican, London, Cheek by Jowl and Moscow Pushkin Drama Theatre in a co-production with the Barbican, Les Gémeaux/Sceaux/Scène Nationale, Centro Dramático Nacional, Madrid (INAEM)). Performance attended: 2019-06-05. See production details at the end of the review.

A DEEP RECTANGULAR CANVAS-COLORED ACTING ARENA SEEMINGLY FLOATED ON THE BARBICAN THEATRE, flanked on either side by four black skeletal lighting stands balancing head-high theater spotlights. The lamps pointed sentry toward a megalithic shape that dominated center stage, its nine face-front rectangular blocks stacked like an oddly stretched and blanched Rubik's puzzle. White light spilled onto either side of the structure before a lighting change signaled the arrival of eight actors in modern dress, each bearing an innocuous tubular-steel stackable chair on which to sit or sprawl, bodies angled away from each other. The disparate grouping comprised an aging leather-clad heavy-metalist, some men in office suits, others more casually dressed, and a catwalk model-inspired partygoer in a voluminous cocktail dress and perilous heels, her head reclining back in apparent exhaustion. The only non-realistic feature common to all was the uniform coal-black eye makeup that was smudged around each actor's eyes, reminiscent of some silent movie-era design choice for accentuating facial expressions.

With actors settled, their non-engagement with each other accentuating their individuality and isolation, the drama commenced with technological wizardry. The face of the figure seated downstage center, side-lit and body addressing the stage-left wings, was captured in crystal clear monochrome close-up by a video camera mounted beneath the off-left rank of spotlights. Projected onto the megalith's forward-facing panels, the giant bespectacled head of Kirill Sbitnev's Tim addressed the audience, his somber delivery introducing the plot of money-crossed lovers and arranged-marriage intrigue, narrated in Russian and translated for Anglophones in the audience by a high-mounted surtitling display panel. With parodic intensity, Tim's opening comments betrayed the company's intent to present an evening of avant garde Eurasia-angst theatrical polemicizing, with a high-capitalist patriarch forcing his defenseless daughter to marry above her rank, while a conniving employee conducted clandestine maneuvers to outwit in the name of love, lust, and lucre. Thus began Declan Donnellan and Nick Ormerod's latest Cheek by Jowl production of The Knight of the Burning Pestle, a 100-minute performance with no interval. London represented the play's sixth 2019 Russo-European tour stop, after visiting three 
venues in Moscow, one in Paris, and one in Madrid, with the production returning to Moscow after its Barbican performances prior to further touring dates in Gdańsk and Toulouse. ${ }^{1}$

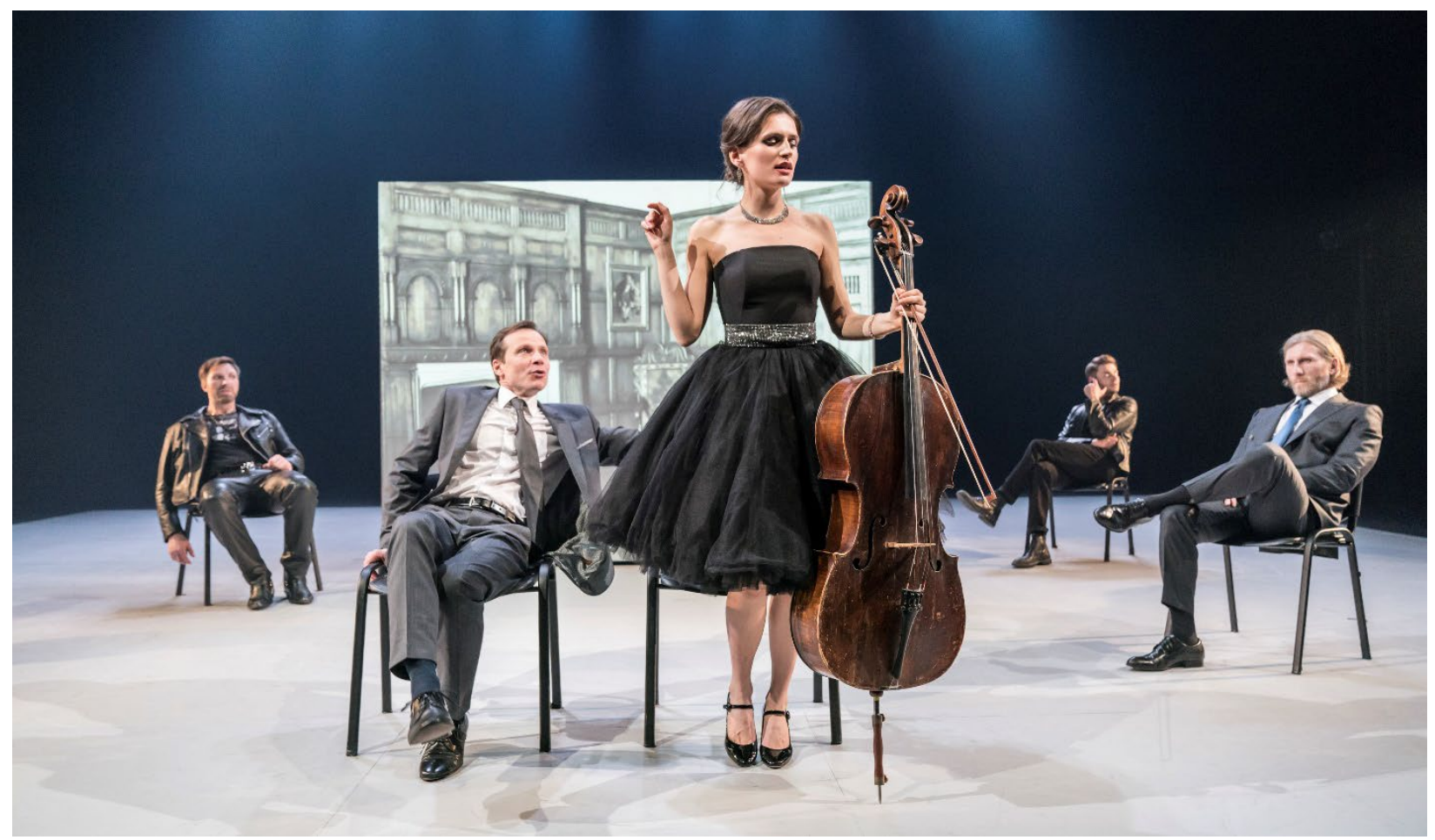

Figure 1. Anna Vardevanian as Luce dutifully gyrates for Humphrey (Andrei Kuzichev) as her father Venturewell (Sergei Miller, seated right) looks on. Photo credit: Johan Persson.

As this opening section unfolded, the uninitiated might rightly have resigned themselves to witnessing another tragicomedic confection, as formulaic in its initial conceit as it inevitably would be in its "happy" outcome. Inevitably, that is, were not some (though possibly not all) of us aware of the comic potential of Frances Beaumont's spectacularly metatheatrical innovation. As all early modernists know, however, Beaumont subverts the cozy discomfort of so traditional a tortured narrative. Instead of actors left free rein to embark on an energetic journey of dramatic re-production - a finitely scripted example of acting physicality and mental skill whose execution inspires awe and wonder (or occasionally stoic ennui) in its entrapped audience-a proverbial spanner was thrust forcibly into the ensuing theatrical works. In this early moment of progressively high onstage drama, a voice from the audience shouted its dissent and demanded the play's alteration to accommodate popular needs. With all the subtlety of a populist antiestablishment coup, a late middle-aged brown-besuited audience member scrambled up to the

\footnotetext{
${ }^{1}$ See Peter Kirwan, Shakespeare in the Theatre: Cheek by Jowl (London: Bloomsbury, 2019), who acknowledges how Cheek by Jowl "continues to innovate," but can make only passing mention of the company's plans to stage its "first Russian production of a non-Shakespearean early modern play," since the 2018 announcement of The Knight of the Burning Pestle was made as Kirwan's "book goes into production" (p. 186).
} 
stage-right off-platform space, all the time insisting the actors succumb to public pressure for a more appealing production, less social commentary and more vaudeville frolic.

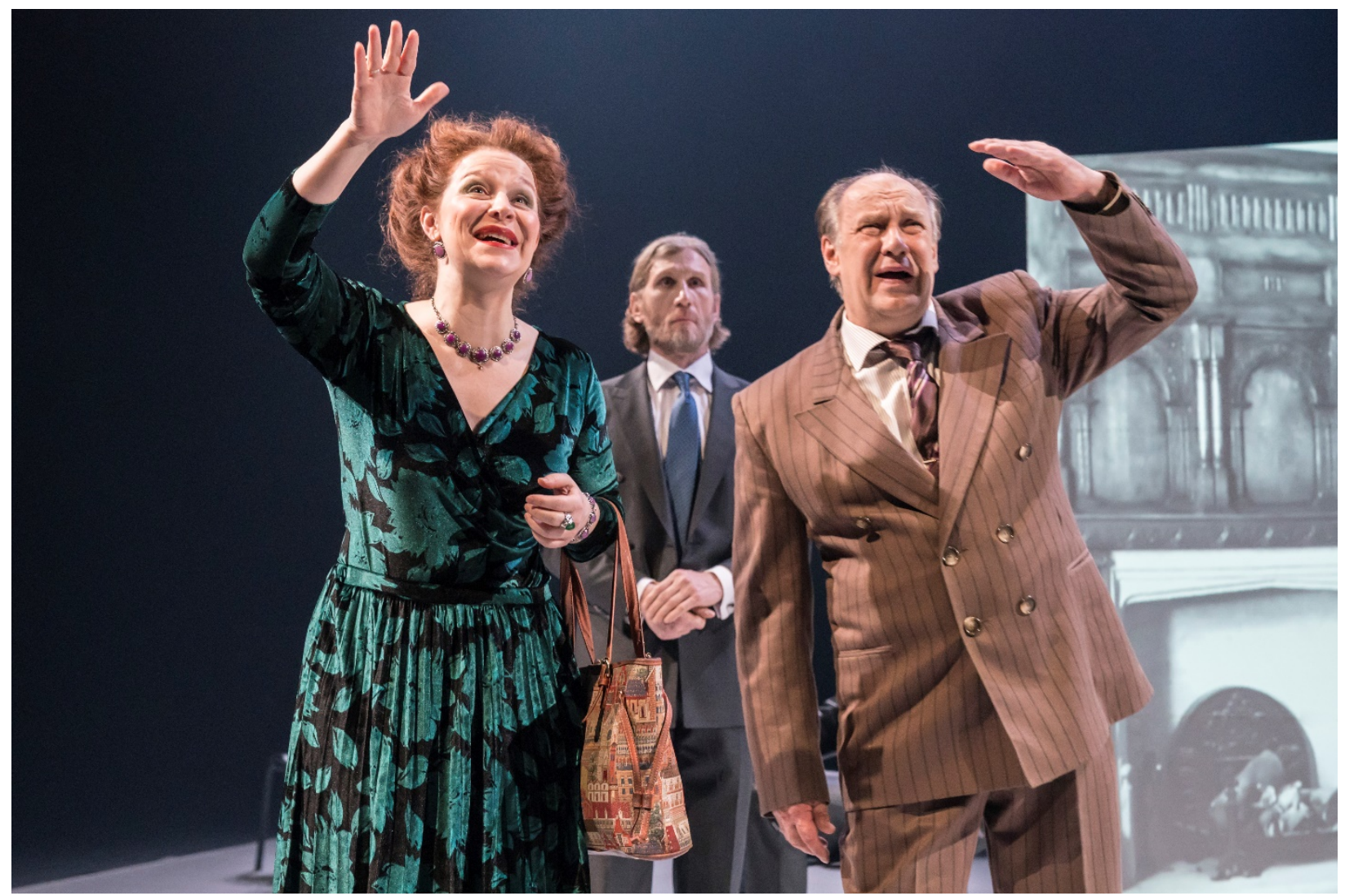

Figure 2. Agrippina Steklova as the Grocer's Wife and Alexander Feklistov as the Grocer wave to Rafe in the Barbican audience, as Sergei Miller's Venturewell (behind) looks disbelievingly on. Photo credit: Johan Persson.

In need of his wife's support, Alexander Feklistov's brash interloper, the Grocer, cajoled his partner into joining him, her gauche reaction upon realizing all eyes now relentlessly stared her way quickly superseded by a shyly arrogant pleasure at becoming the center of attention. Like a child caught in a school-play spotlight, Agrippina Steklova's matronly tourist, the Grocer's Wife, accepted her new role as artistic adviser with self-consciously giggling delight. While this quintessential city comedy was still firmly rooted in London, the interlopers added ironic references that highlighted the internationalist credentials of the production's topical humor. The Grocer and his wife had now become Russian tourists, commenting harshly on how expensive the Brexit-dominated UK capital had become, and noting wryly that they had attended the Barbican performance only because "The Lion King was sold out!" Now forced into their second-best evening's entertainment, the Grocer's Wife found herself pleasantly star-struck by her proximity to a supposed TV personality—-the suave Humphrey of Andrei Kuzichev-and adamant in her naïve belief in the moral decrepitude of other actors, for whom she immediately expressed her disgust. Empowered by her onstage presence, the Wife offered irrepressibly ill- 
timed commentary that disrupted the "real" actors' thought-processes while annoying those less willing to accept the outrageous demands of their newly-found lay directors.

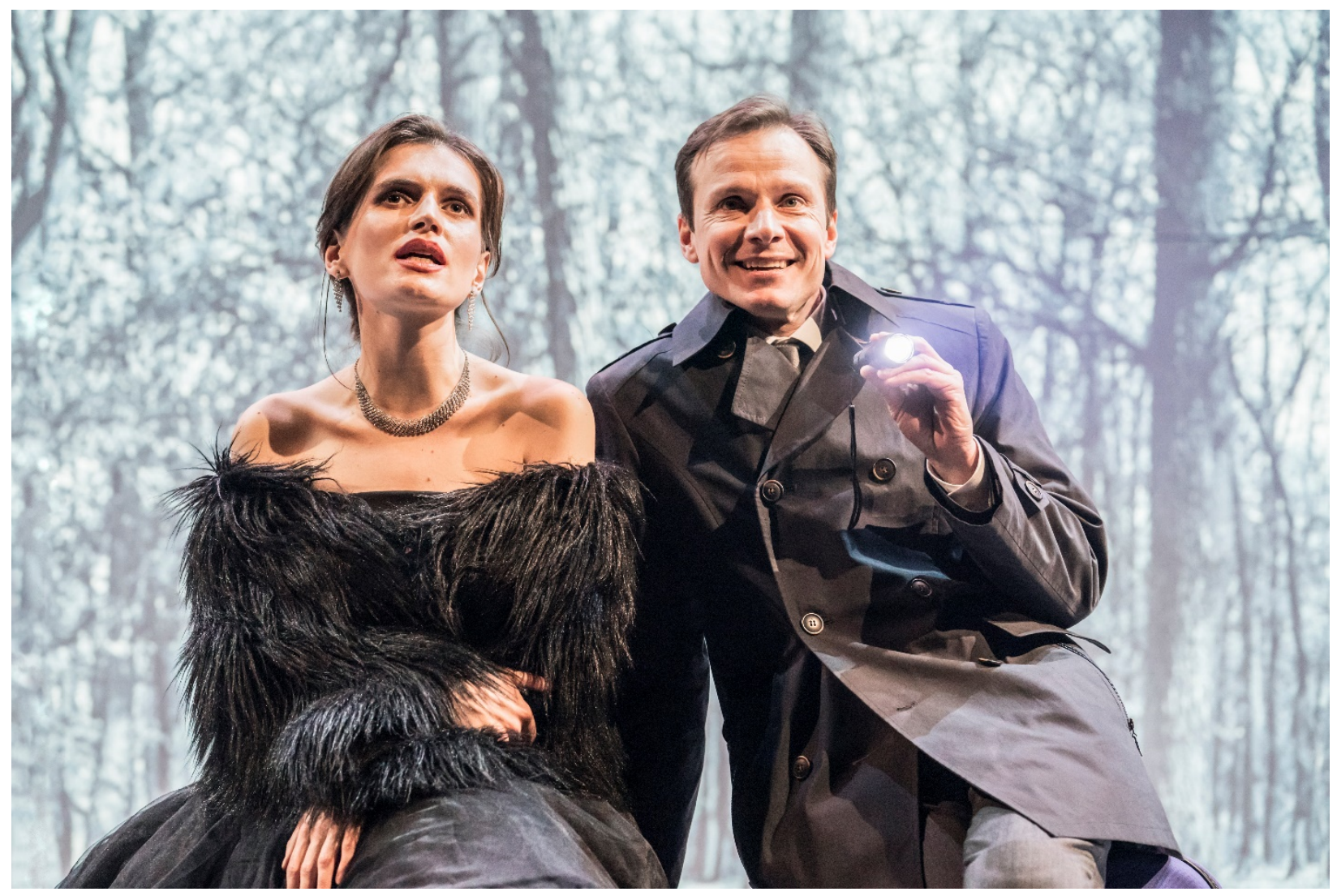

Figure 3. Anna Vardevanian as Luce, longing for her true love Jasper, with Andrei Kuzichev as Humphrey shining a flashlight in the forest. Photo credit: Johan Persson.

The most outrageous demand of all, of course, was that their apprentice Rafe, seated way back in the Barbican stalls and played with puerile arrogance by Nazar Safonov, should be inserted into the serious drama as a pseudo-romance knightly figure, complete with wholly inappropriate narrative features at odds with the modern realism of the intended original. Rafe too scrambled onstage and proved his dramatic worth by spouting not only Hotspur's "pluck bright honor" from Henry IV Part 1, but also several other set-speech snippets from Shakespeare ("To be or not to be," and others), all with the dramatic skill and delivery of one whose opinion of their own talent was only outweighed by the reality of their embarrassing theatrical incompetence. While some of the cast expressed their open dismay at the suggestion, others conceded that, to avoid further disruption, they would accommodate the interlopers' demands. Hurriedly bundled offstage, Rafe retired to discover what costume and props might be available, while the actors continued 
with their original production, now forced to reenergize themselves after so many unwelcome false starts.

With the arrogant Rafe safely stowed backstage, for the moment, the original acting company embarked again on their concept-driven drama. The Grocer and his wife still refused to hide their disdain for this resumed dramatic narrative, especially when Anna Vardevanian, the actor playing Luce, squatted to urinate behind a forest of projected trees. Knowingly responding to his wife's query-"Is that normal?"-the Grocer explained with self-congratulatory authority, "It's modern theater." Modern theater it might be, but, as the overhead projected surtitling of the play's fourhundred-year-old English dialogue confirmed, along with the impeccable pronunciation of place and character names by the Russian actors, this version remained fundamentally faithful in its translation of

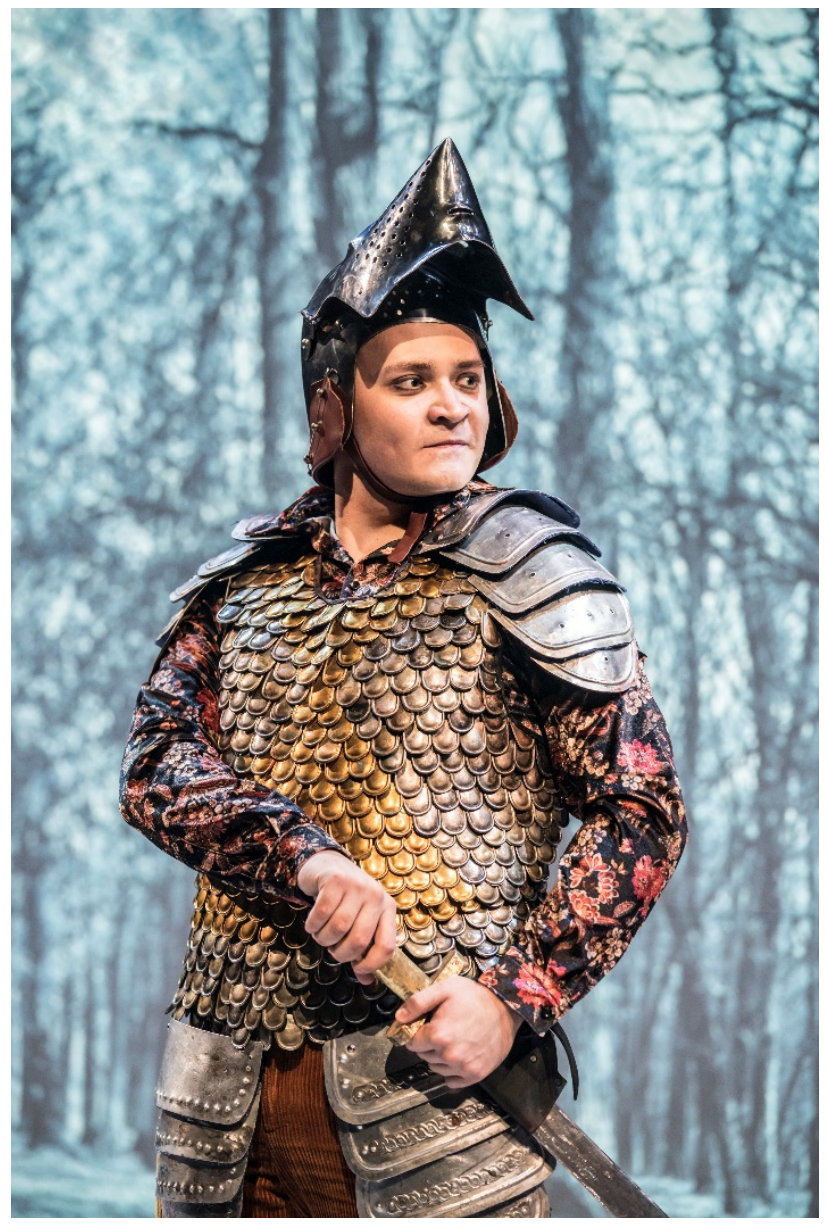

Figure 4. Nazar Safonov as the arrogant knightly Rafe. Photo credit: Johan Persson.

Beaumont's original early modern text. Topical and original, the production also jolted us into its surreal Barbican world, especially when a frustrated British stage manager metatheatrically confronted the Russian interlopers onstage, only to be dismissed by the Grocer's Wife's inevitable, "No speak the English!"

Interviewed prior to its short Barbican run, Donnellan offered insights into his directorial choices and the topicality he saw in Beaumont's play. Claiming The Knight of the Burning Pestle as a "unique piece of meta-theatre" that is "daring and centuries ahead of its time," Donnellan described how radical it must have been to watch a play being "changed by frustrated audience members," who demanded instead "something more popular, more positive, more glamorous." Despite the "very funny" humor of this anarchic audience-empowered situation, Donnellan confirmed his opinion that the play remains "also very dark." Such darkness, Donnellan explained, stemmed from Beaumont writing "at the brink of a revolution," whereby, within only a "few years," a "new and highly popular nationalist government seized power through violence 
and closed down every single theatre" (Donnellan). Consequently, the choice to direct the play in 2019 was obvious to Donnellan:

Everything seems new about The Knight of the Burning Pestle! Today, the fantasy is that everyone can be an expert, without any experience, everyone can be a celebrity, everyone can tell the story, everyone can manipulate and control facts. Perhaps we have always been like that, only now we have the technology to make the delusion seem more real. What seems new is a confusion between democracy and capitalism. One-click government and the people have the right to get what they want. Like Amazon, like parliament. (Donnellan)

For an international audience in London, all too aware of the political upheaval surrounding the UK's Brexit shenanigans, and conscious of the shifting sands of public opinion and populist power, Donnellan's choice seemed timely in its Amazon/Facebook/Twitter-feed pseudodemocratizing focus.

Indeed, only twenty days after the Cheek by Jowl Barbican performances, the frightening political truth behind Donnellan's one-click government "fantasy" seemed highlighted by Vladimir Putin's much-publicized remarks, where he "trumpeted the growth of national populist movements in Europe and the US, crowing that liberalism was spent as an ideological force" (Barber and Foy 1). Quoted as stating that "the liberal idea" had "outlived its purpose" and "become obsolete" since coming "into conflict with the interests of the overwhelming majority of the population," Putin maintained that the liberal-minded "cannot simply dictate anything to anyone just like they have been attempting to do over the recent decades" (Barber and Foy 1). With "liberal governments" no longer acting "to reassure citizens," choosing "instead" to pursue, what Putin declared to be, "a mindless multiculturalism embracing, among other things, sexual diversity," the Russian president claimed to see "national populism" as "fuelled by public resentment about immigration, multiculturalism and secular values at the expense of religion" (Barber and Foy 1). The perceived cynicism inherent in Putin's "cult of celebrity" religious posturing- "Have we forgotten all of us live in a world based on biblical values?"-seemed to confirm Donnellan's warning about social media delusory news fakedom (Barber and Foy 9). With manipulation and control of facts, as Donnellan suggested, held responsible for the growth in vociferous populism, that same technology-which ironically makes this essay accessible while likewise silencing legitimate debate in favor of illusory democratic engagement-also elevated The Knight of the Burning Pestle's potential as an anti-populist, anti-nationalistic theatrical device.

As this essay argues, however, the overtly apposite political implication of Beaumont's play in its twenty-first-century context also highlights an alternative nightmare scenario, most obvious to any commentator with commercial acting experience. Donnellan might understandably, and 
successfully, concentrate on the political implication of nations steering their democratic or autocratic courses through a virtual minefield of uncontrolled though manipulable social media discourse. Nonetheless, the Cheek by Jowl performances exposed that most easily overlooked cultural phenomenon: the traumatic threat of populism on the creative industries, especially upon those whose livelihoods depend on artistic freedom of expression. We might laugh at the metatheatrical audacity of Beaumont's citizen anti-aesthetes, or smirk at the Putinesque vox populi russicum of their brash directives, but, when viewed through the disbelieving lenses of the actors, such populist interventionism appears starkly in all its cold, heartless, straitjacketing fury.

As an actor watching actors portray the fear, the anger, the mental anguish, the professional disgust and disbelief, and finally the resigned torment of conceding to populist artistic demands, I saw Beaumont's astute observational impulses with newfound clarity. Then and now, the powerlessness of actors-financial, political, and social-is pushed painfully to the fore. Whether at the hands of monetarily constrained theater producers and directors, political censors or commentators, self-aggrandizing critics, or entertainment-demanding consumers, actors must remain those malleable clay models, ever willing to submit to others' wishes because of the precariousness of their working existence. Later literary analysts and theater historians might view Beaumont's "revolution" with intellectual glee. In 1607 and in 2019, the "revolution," for any actor, was seeing their profession presented in impotent and creatively enslaved reality.

When actors did deign to express dismay during the production, each individual revolutionary outburst was dismissed as a histrionic childish fit by their onstage invaders. Never a favorite of Steklova's Grocer's Wife, the patriarchally dominated Luce, for example, was portrayed with high-pitched vocal submissiveness by Vardevanian. Luce seemed powerless when manipulated by the men in her life, most starkly demonstrated by the heroin-like injection she selfadministered as her father loomed over her collapsed and exhausted doll-like figure. When pushed to her limit by the side-stage amateur directors, however, Vardevanian let her character mask drop, her lapse in concentration accompanied by a plummetingly deep tonal shift in the pitch of her voice. Luce the character became Vardevanian the actor, her aggression manifesting in maliciously barked responses to the Grocer's Wife, who sneered with full-figured dismissiveness at the far younger, more glamorous, albeit wafer-slim female actor. Suddenly jolted into remembering the production demands for Luce's contrived vocal tone, Vardevanian returned to her character's high-pitched delivery, though daggers of actorly wrath continued to fly with merciless regularity toward her directorial nemesis seated grandiosely with her Grocer husband near the wings. 
Vardevanian and her fellow actors did achieve one moment of counter-revolutionary power, however, when conceding to the farcical demand to integrate Rafe's narrative of a knightly journey to the court of Moldavia. No longer the puppets of their new masters, the troupe appeared onstage fully armed with extemporizing skills as they burlesqued their way through this outrageous theatrical moment. Even Vardevanian, presenting her Moldavian princess more like a soft-porn starlet than regal suitor, was free to express her powerful sexuality, unfettered by the original production's demands for type-cast passivity. As the Grocer became voyeuristic handheld-camera-wielding documenter of the onstage mayhem, the actors cavorted and contorted in outrageously mismatched costumes and wigs, their anarchic vision of populist appeal reminiscent of 1970s music videos that misappropriated Bowie's Ziggy Stardust persona with laughable ineptness.

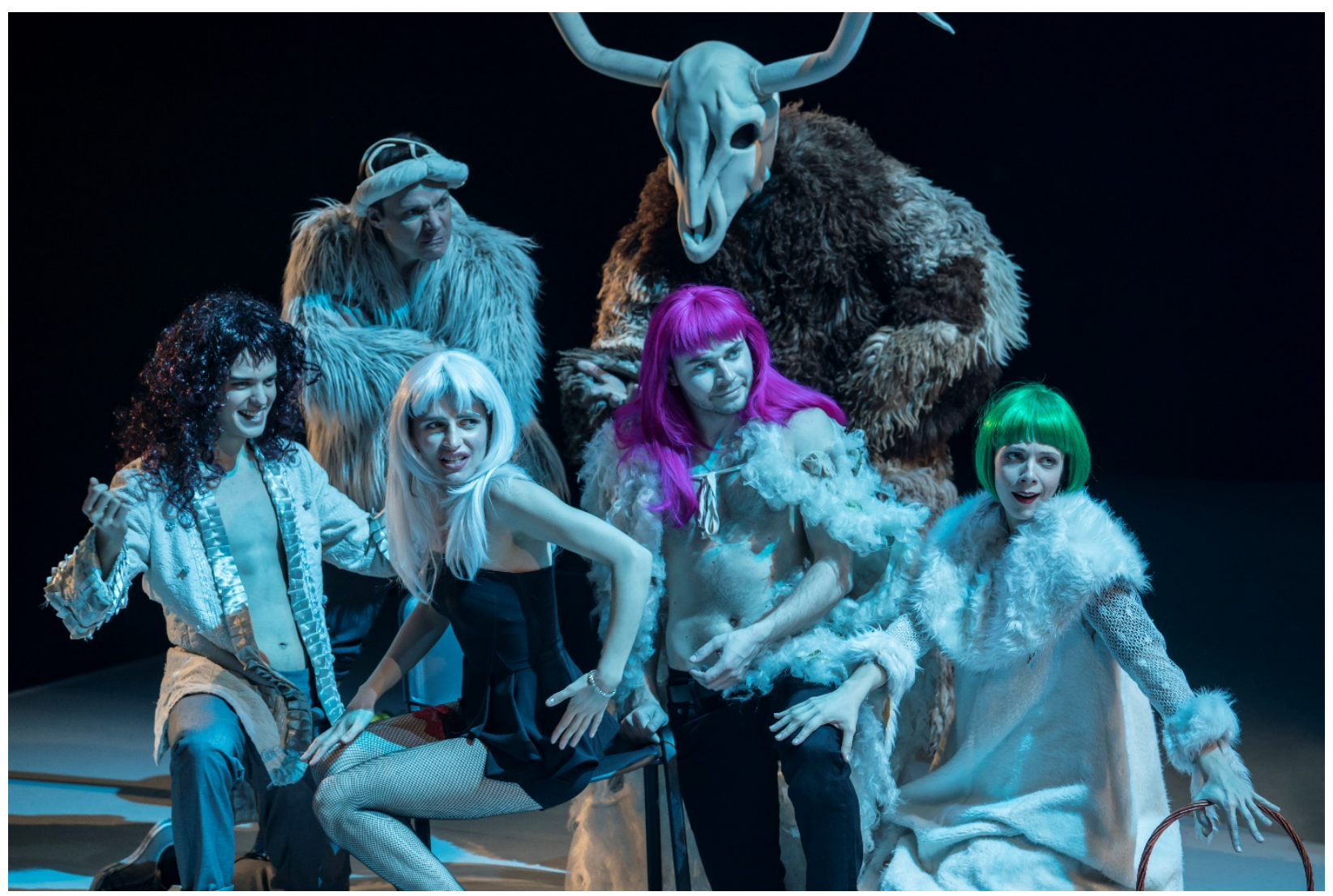

Figure 5. Anna Vardevanian's Luce (seated wearing a blonde wig), with the remaining Company, assuming the sensual Moldavian princess role in Rafe's absurd additional narrative. Photo credit: Johan Persson

The moment of raucous rebellion now past, and Rafe's absurd and prolonged death scenecomplete with the ubiquitous bloodied arrow through the head-consigned to comic memory, the cast returned to their devastated original play. Unsure where or what their characters could do to restore creative order, the exhausted troupe found their dramatic narrative spiraling uncontrollably to its conclusion, and away from their creative grasp. Allowed at last to complete 
their journeys, the actors raced through their muddled denouements only to unite in a final onstage tableau of huddled breathless completion. The lights might fade, then reenergize, but the audience's applause for a raucous evening's entertainment, complete with populist citizen directors and Rafe's ill-talented youthful enthusiasm, was greeted not by the expected actors' smiles and bows. Instead, the cowered, sweat-drenched group stared in wide-eyed, wild-eyed disbelief into the auditorium, as if hearing not clapping but jeering. The discomfort of the actors, traumatized into passive submission, only added to the uncomfortable humor of the situation. Humor perhaps, but this The Knight of the Burning Pestle, intended as a comment on capitalism and consumerism in the hands of over-powerful populists, trod painfully close to social and political commentary of a different sort: the harrowing effect of finding one's artistic freedom suppressed, and the actor's ultimate nightmare of being forced to perform an embarrassing drama. With this ultimate example of the powerlessness of the performer, the liberal idea of freedom of expression seemed indeed to have outlived its purpose. Perhaps Putin's words will haunt further iterations of this astonishingly entertaining production. Let's hope Putin was neither offended by, nor in the audience for, the anti-populist nuance of The Knight of the Burning Pestle when it returned to its Moscow home.

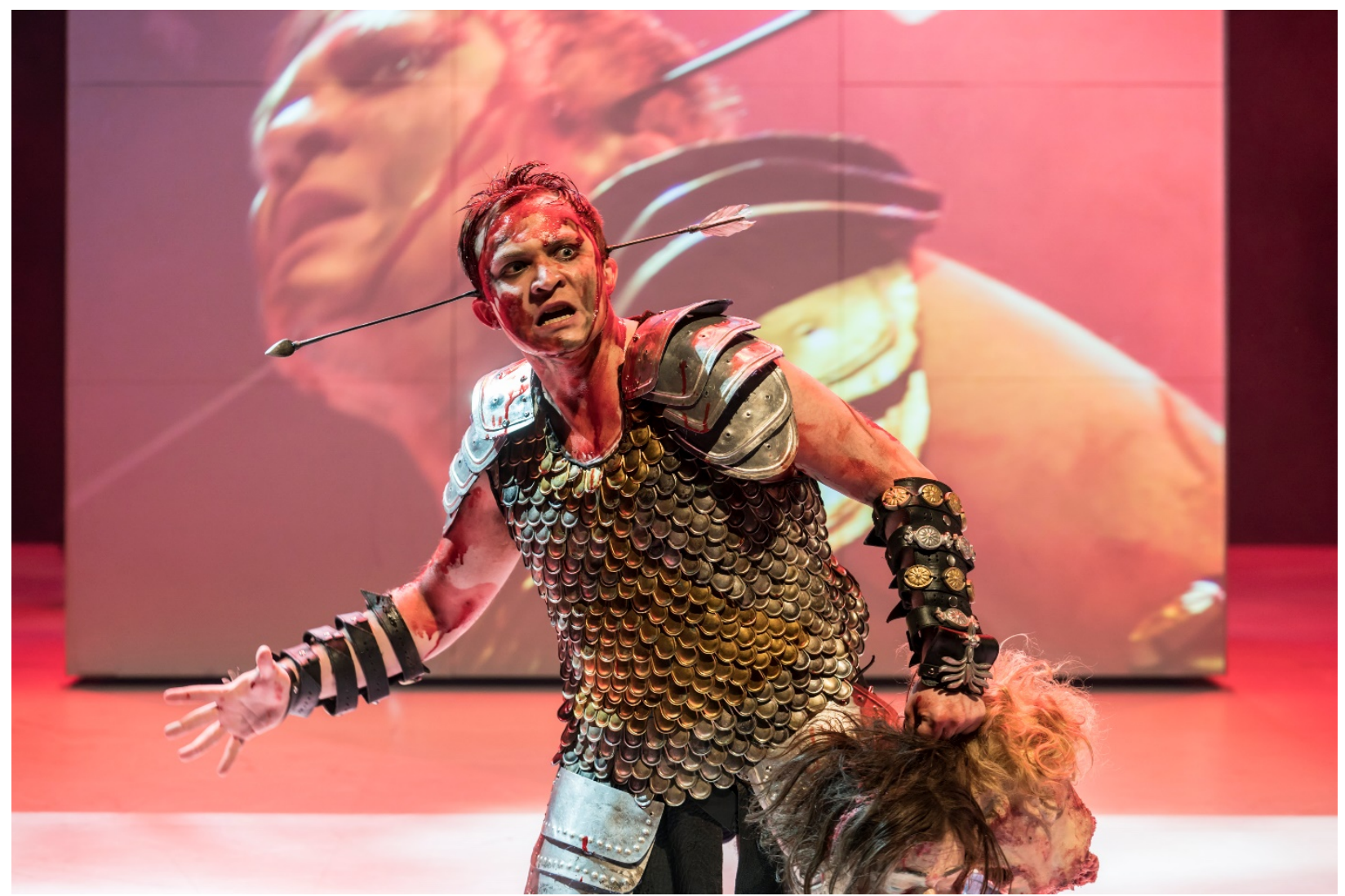

Figure 6. Nazar Safonov overacting the histrionic demise of Rafe's burning pestle knight. Photo credit: Johan Persson. 


\section{References}

Barber, Lionel, and Henry Foy. “The liberal idea has become obsolete': Vladimir Putin, Exclusive Interview." Financial Times, 28 June 2019, pp. 1 \& 9.

Donnellan, Declan. "We are each of us unique'-Declan Donnellan on The Knight of the Burning Pestle." Barbican.org.uk, Read, Watch \& Listen, 13 May 2019. URL:

https://www.barbican.org.uk/read-watch-listen/we-are-each-of-us-unique-declandonnellan-on-the-knight-of-the-burning-pestle.

Kirwan, Peter. Shakespeare in the Theatre: Cheek by Jowl. Bloomsbury, 2019.

\section{Links}

Barbican Theatre. https://www.barbican.org.uk/our-story/our-building/our-venues

Cheek by Jowl. https://www.cheekbyjowl.com/ 


\section{Production Details}

\section{General}

Title

Year

Theater Company

Theater

Start Date

End Date

\section{Cast}

GROCER

GROCER'S WIFE

RAFE

VENTUREWELL

LUCE

JASPER

HUMPHREY

Mr. MERRYTHOUGHT

MRS. MERRYTHOUGHT

MICHAEL

TIM

\section{Creatives}

DiRECTOR
DESIGNER
LigHTING DESIGNER
COMPOSER
CHOREOGRAPHER
ASSISTANT DIRECTOR

The Knight of the Burning Pestle

2019

Cheek by Jowl and Moscow Pushkin Drama Theatre

Barbican, London

2019-06-05

2019-06-08
ALEXANDER FEKLISTOV

AGRIPPINA STEKLOVA

NAZAR SAFONOV

SERGEI MILLER

ANNA VARDEVANIAN

KIRILL CHERNYSHENKO

ANDREI KUZICHEV

Alexei RakHMANOV

ANNA KARMAKOVA

DANILA KAZAKOV

KIRILL SBITNEV

DECLAN DONNELLAN

NICK ORMEROD

ALEXANDER SiVAEV

PAVEL AKIMKIN

IRINA KASHUBA

IGOR TEPLOV 